DR CHRIS MCCORMACK (Orcid ID : 0000-0003-2549-0475)

DR CARRIE VAN DER WEYDEN (Orcid ID : 0000-0001-6655-9876)

Article type : Research Letter

\title{
A comparative analysis of histone deacetylase inhibitors for the treatment of mycosis fungoides and Sézary syndrome
}

\section{Authors:}

T. Papps ${ }^{1}$, C. McCormack ${ }^{1}$, O. Buelens ${ }^{1}$, C. Van der Weyden ${ }^{1}$, R. Twigger ${ }^{1}$, B. A. Campbell ${ }^{2}$, M. Dickinson ${ }^{1}, \mathrm{H}$. Miles Prince ${ }^{1,3}$

1. Division of Cancer Medicine, Peter MacCallum Cancer Centre and Sir Peter MacCallum Department of Medical Oncology University of Melbourne, Australia

2. Department of Radiation Oncology, Peter MacCallum Cancer Centre

3. Molecular Oncology and Cancer Immunology Epworth Healthcare

\section{Address for correspondence:}

Professor $\mathrm{H}$ Miles Prince

Molecular Oncology and Cancer Immunology Epworth Healthcare

140 Clarendon Street East Melbourne

Victoria 3002, Australia.

Miles.Prince@petermac.org

\section{Potential Conflicts of Interest:}

This is the author manuscript accepted for publication and has undergone full peer review but has not been through the copyediting, typesetting, pagination and proofreading process, which may lead to differences between this version and the Version of Record. Please cite this article as doi: $\underline{10.1111 / B] D .18522}$

This article is protected by copyright. All rights reserved 
HMP has received honorarium for advisory roles and research funding from Celgene, Novartis and Merck.

MD has received honorarium for advisory roles from Celgene and Novartis.

$\mathrm{CMcC}$ has received honorarium for advisory roles for Merck

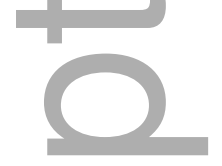

$\square$

Two histone deacetylase inhibitors (HDACi), vorinostat and romidepsin have been approved by regulatory agencies in parts of the world for the treatment of relapsed/refractory Mycosis Fungoides (MF) and Sézary Syndrome (SS) based on positive Phase II trial results. ${ }^{1,2}$ Panobinostat has activity in MF/SS, and is approved in the United States for the treatment of myeloma. ${ }^{3} \mathrm{HDACi}$ are of different classes, with vorinostat and panobinostat both hydroxamic acids with pan-HDAC inhibitor activity, and romidepsin a cyclic peptide with specificity to Class I HDAC. Moreover, the mechanism of action of $\mathrm{HDACi}$ are not fully understood and there are no direct comparative analyses between HDAC inhibitors to aid the physician in selecting between HDACi agents for MF/SS. ${ }^{4}$

Previously, we reported a comparative analysis between systemic therapy agents in the treatment of MF/SS, utilizing "time to next treatment" (TTNT) to assess and compare the clinical value of these therapies. ${ }^{5}$ In that study, we observed that the median TTNT for all treatments was 5.4 months. Here, we now review the use of HDACi in the treatment of patients with MF/SS at our institution, and examine TTNT for three HDACi: romidepsin, vorinostat and panobinostat. A retrospective analysis of patients' first treatment with a HDACi was performed, and the primary endpoint was TTNT, using the methodology previously described. ${ }^{5}$ In Australia, currently all drugs are approved by the Therapeutics Goods Administration, vorinostat for relapsed/refractory cutaneous $\mathrm{T}$ cell lymphoma, romidepsin for relapsed/refractory peripheral T cell lymphoma and panobinostat for myeloma. During the time-frame of the analysis the drugs had not necessarily achieved approval and were variously obtained through standard prescription, compassionate programmes or clinical trial. 
Eighty-two patients were treated: 58 MF, 24 SS. Patient characteristics are summarized in Table 1. All patients had multiply-relapsed disease; overall median number of previously failed lines of therapy was 4 (range: 1-14). There were no differences between the HDACi with respect to age, gender, stage, or number of prior therapies. The overall median TTNT was 5.5 months (range: 1-124). There were no significant differences in TTNT between the HDACi therapies (Table 1 and Figure 1). Adverse events were consistent with that reported in previous clinical trials ${ }^{1,2,3}$. Indeed, few patients discontinued therapy for adverse events (vorinostat $=2$, romidepsin $=1$ and panobinostat $=1$ ).

As this was a retrospective analysis we cannot exclude the possibility of some selection bias as to the choice of HDACi utilized. Given that romidepsin requires regular intravenous administration, it is possible that the clinician's drug choice may have been influenced by individual patient characteristics. Some patients received panobinostat or romidepsin in the context of a clinical trial which also may have had some influence on drug selection choice.

We specifically examined vorinostat according to diagnosis: the median TTNT was 4 months for MF (range: 1-38) and 7 months for SS (range: 1-34 months); at 24 months, approximately $10 \%$ of patients had not required another treatment in both disease groups. Of note, vorinostat was the control arm of the MAVORIC study where a median progression free survival of 3.1 months [95\% confidence interval of 2.9-4.1 months] was reported ${ }^{6}$. Moreover, a recent analysis of the MAVORIC study presented in abstract form demonstrated a TTNT of 3.5 months [95\% confidence interval of 3.1-4.3 months] ${ }^{7}$. These results are strikingly similar to our TTNT of 4 months and confirms the value of TTNT as clinically meaningful endpoint, particularly in retrospective analyses of realworld studies where detailed global response scoring as used in prospective clinical trials is not always feasible. 
The median TTNT for the entire group for refractory, early stage disease $(n=25)$ was 7 months (range: $2-124)$, and for advanced stage disease $(n=57)$ was 5 months (range: 1 112). Of note, for each drug there were some patients who achieved long-term disease control. We examined the seven patients who achieved disease control beyond 24 months; there were no differences between this group of patients and the whole cohort in terms of age, gender, number of prior therapies, MF vs. SS, early- vs advancedstage, and drug received (romidepsin=3, vorinostat=2, panobinostat=2).

In conclusion, we demonstrate that the three HDACi produced equivalent TTNT in patients with multiply-relapsed MF/SS. Further, approximately $10 \%$ of patients achieved prolonged disease control with a TTNT greater than 24 months.

Table 1: Mycosis fungoides and Sézary syndrome patients treated with first HDAC inhibitor

\begin{tabular}{|l|c|c|c|c|}
\hline HDACi & Vorinostat & Romidepsin & Panobinostat & All HDACi \\
\hline Number & 43 & 17 & 22 & 82 \\
\hline $\begin{array}{l}\text { Median Age in years } \\
\text { (Range) }\end{array}$ & $66(32-86)$ & $62(37-73)$ & $57(21-79)$ & $63(32-86)$ \\
\hline Gender Male/Female & $22 / 21$ & $11 / 6$ & $10 / 12$ & $44 / 48$ \\
\hline Early Stage IA to IIA (\%) & $11(25 \%)$ & $8(47 \%)$ & $6(33 \%)$ & $25(30 \%)$ \\
\hline $\begin{array}{l}\text { Advanced Stage IIB to IVB } \\
(\%)\end{array}$ & $32(75 \%)$ & $9(53 \%)$ & $16(67 \%)$ & $57(70 \%)$ \\
\hline $\begin{array}{l}\text { Median Number of Prior } \\
\text { Treatments (Range in } \\
\text { months) }\end{array}$ & $4(1-14)$ & $4(1-11)$ & $3(1-13)$ & $4(1-14)$ \\
\hline $\begin{array}{l}\text { Median TTNT in months } \\
\text { (Range) }\end{array}$ & $5(1-38)$ & $6(1-124)$ & $9(1-112)$ & $5.5(1-124)$ \\
\hline
\end{tabular}

TTNT, time to next treatment; HDACi, histone deacetylase inhibitor. 


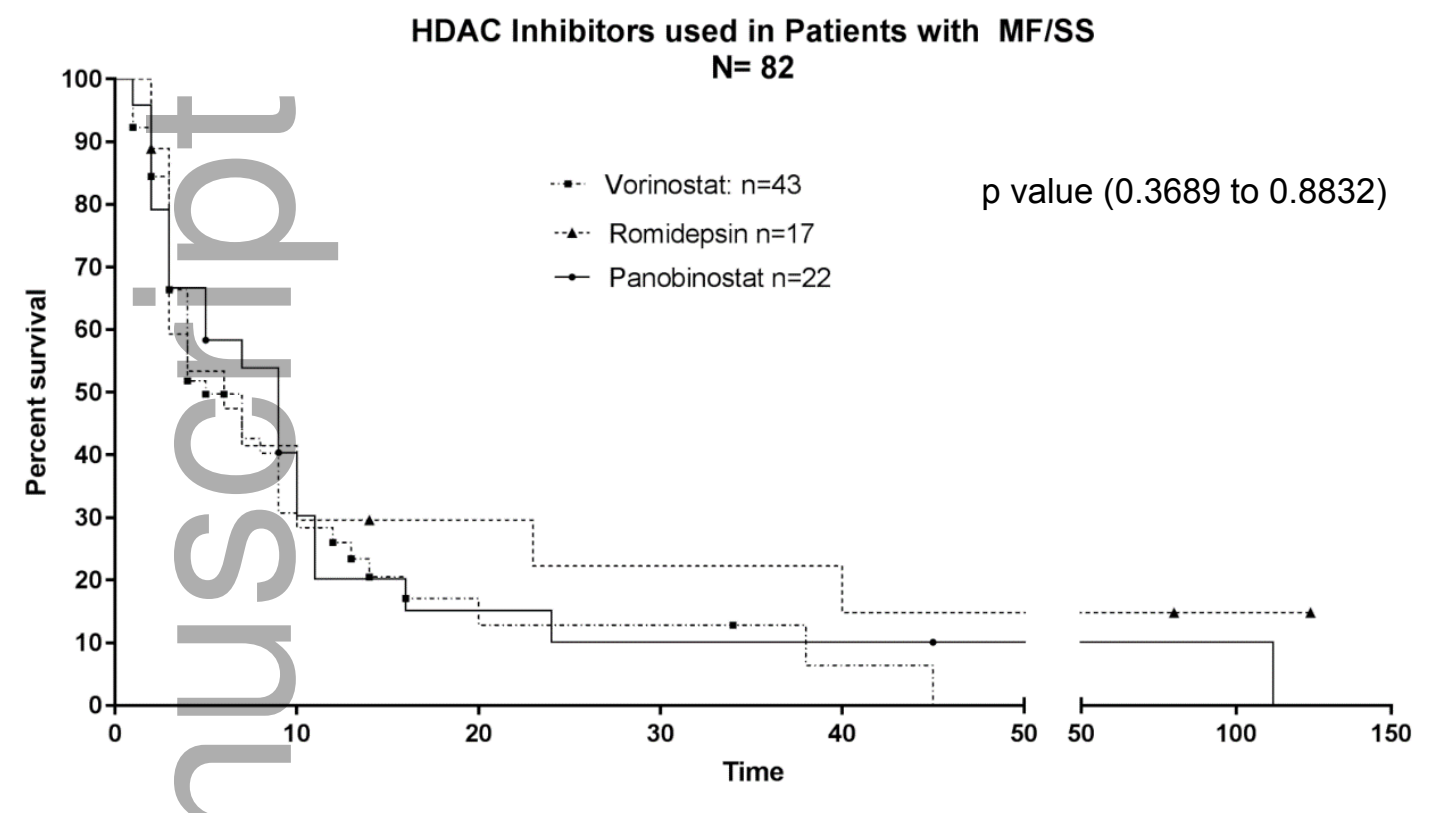

Figure 1. TTNT for combined MF/SS patients treated with HDACi. References

1. Duvic M, Talpur R, Ni X, Zhang C, Hazarika P, Kelly C, Chiao JH, Reilly JF, Ricker JL, Richon VM, Frankel SR. Clinical trials and observations - phase 2 trial of oral vorinostat (suberoylanilide hydroxamic acid, sAHA) for refractory cutaneous t-cell lymphoma. Blood. 2007;109(1):31-9.

2. RL Piekarz, R Frye, M Turner, JJ Wright, SL Allen, MH Kirschbaum, J Zain, HM Prince, JP Leonard, LJ Geskin, C Reeder, D Joske, WD Figg, ER Gardner, SM Steinberg, E Jaffe, M Stetler-Stevenson, A Tito Fojo, SE Bates. A MultiInstitutional Phase II Trial of the HDAC Inhibitor Romidepsin as Monotherapy for Patients with Cutaneous T-cell Lymphoma J Clin Oncol 2009: 27; 5410-7.

3. M Duvic, R Dummer, JC Becker, N Poulalhon, PO Romero, MG Bernengo, C Lebbé, C Assaf, M Squier, D Williams, M Marshood, F Tai, HM Prince. Panobinostat Activity in Both Bexarotene-Exposed and -Naïve Patients With 
Refractory Cutaneous T-Cell Lymphoma: Results of a Phase II Trial. Eur J Cancer 2013; 48: 386-394[IF: IF:5.536].

4. M Dickinson, R Johnstone, HM Prince. Histone deacetylase inhibitors: potential targets responsible for their anti-cancer effect. Investigational New Drugs. The Journal of New Anticancer Agents 2010;28 Suppl 1:S3-20.

5. CF Hughes, A Khot, C McCormack, S Lade, DA Westerman, R Twigger, O Buelens, K Newland, C Tam, M Dickinson, G Ryan, D Ritchie, C Wood, HM Prince. The lack of durable disease control with chemotherapy for mycosis fungoides and Sézary syndrome: a comparative study of systemic therapy. Blood 2015; 125:71-81.

6. YH Kim, M Bagot, L Pinter-Brown, A Rook, PL Porcu, SM Horwitz, S Whittaker, Y Tokura, M Vermeer, PL Zinzani et al. Mogamulizumab versus vorinostat in previously treated cutaneous T-cell lymphoma (MAVORIC): an international, open-label, randomised, controlled phase 3 trial. The Lancet Oncology. 2018 Aug;19(9):1192-1204. DOI:https://doi.org/10.1016/S1470-2045(18)30379-6

7. YHKim, PL Ortiz-Romero, B Pro, L Sokol, J Scarisbrick, A Musiek, M Vermeer, R Dummer, A Halwani, MT Fierro, J Moriya, M Leoni, M Bagot. Time to next treatment in patients with previously treated cutaneous T-cell lymphoma (CTCL) receiving mogamulizumab or vorinostat: A MAVORIC post-hoc analysis. Haematol Oncol 2019; 37, Issue S2; 285.Abstract 231. $15^{\text {th }}$ International Conference on Malignant Lymphoma Palazzo dei Congressi, Lugano. 


\section{University Library}

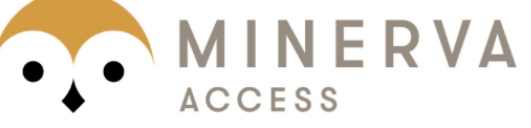

A gateway to Melbourne's research publications

Minerva Access is the Institutional Repository of The University of Melbourne

Author/s:

Papps, T;McCormack, C;Buelens, O;Van der Weyden, C;Twigger, R;Campbell, BA;Dickinson, M;Prince, $\mathrm{HM}$

Title:

A comparative analysis of histone deacetylase inhibitors for the treatment of mycosis fungoides and Sezary syndrome

Date:

2020-02-01

Citation:

Papps, T., McCormack, C., Buelens, O., Van der Weyden, C., Twigger, R., Campbell, B. A., Dickinson, M. \& Prince, H. M. (2020). A comparative analysis of histone deacetylase inhibitors for the treatment of mycosis fungoides and Sezary syndrome. BRITISH JOURNAL OF DERMATOLOGY, 182 (2), pp.497-498. https://doi.org/10.1111/bjd.18522.

Persistent Link:

http://hdl.handle.net/11343/286414 